\title{
2021 Handbook of Florida Water Regulation: Water Wells ${ }^{1}$
}

\author{
Michael T. Olexa, Tatiana Borisova, and Jana Caracciolo
}

\section{Preface}

This handbook is designed to provide an accurate, current, and authoritative summary of the principal federal and state (Florida) laws that directly or indirectly relate to agriculture. This handbook provides a basic overview of the many rights and responsibilities that farmers and farmland owners have under both federal and state laws as well as the appropriate contact information to obtain more detailed information. However, the reader should be aware that because the laws, administrative rulings, and court decisions on which this handbook is based are subject to constant revision, portions of this publication could become outdated at any time. Several details of cited laws are also left out due to space limitations. This handbook is provided as an educational text for those interested in water use and water resource issues in Florida.

This handbook is distributed with the understanding that the authors are not engaged in rendering legal or other professional advice, and the information contained herein should not be regarded as a substitute for professional advice. This handbook is not all inclusive in providing information to achieve compliance with the federal and state laws and regulations governing water protection. For these reasons, the use of these materials by any person constitutes an agreement to hold harmless the authors, the UF/IFAS Center for Agricultural and Natural Resource Law, and UF/IFAS Extension for any liability claims, damages, or expenses that may be incurred by any person as a result of reference to or reliance on the information contained in this handbook. Note: UF/IFAS is the acronym for University of Florida, Institute of Food and Agricultural Sciences.

\section{Water Wells Overview}

Federal law does not directly regulate the construction of water wells. However, because there is potential for groundwater pollution and other environmental damage through well structures, some of the broad federal environmental protection statutes might come into play. For example, seepage of hazardous waste from a polluted well that contaminated one of Florida's aquifers would come under the Comprehensive Environmental Response, Compensation, and Liability Act's (CERCLA) cleanup provisions (see FE584, CERCLA).

At the state level, the Florida Department of Environmental Protection (FDEP), through Chapter 373, Florida Statutes, Section 373.308, has delegated most of its statutory authority to regulate water wells to the individual Florida water management districts (FWMD), and therefore the appropriate FWMD should always be contacted before taking any action involving water wells. The statutes and rules are designed to safeguard both the quality of water extracted from the wells and the quality and quantity of water in

1. This document is FE603, one of a series of the Food and Resource Economics Department, UF/IFAS Extension. Original publication date October 1998. Revised June 2017 and April 2021. Visit the EDIS website at https://edis.ifas.ufl.edu for the currently supported version of this publication.

2. Michael T. Olexa, professor, Food and Resource Economics Department, and director, UF/IFAS Center for Agricultural and Natural Resource Law; Tatiana Borisova, associate professor, Food and Resource Economics Department; and Jana Caracciolo, student, Levin College of Law; UF/IFAS Extension, Gainesville, FL 32611.

The Institute of Food and Agricultural Sciences (IFAS) is an Equal Opportunity Institution authorized to provide research, educational information and other services

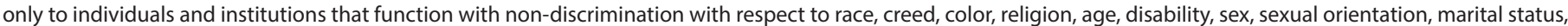

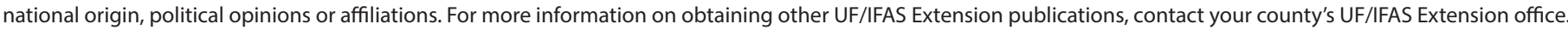
U.S. Department of Agriculture, UF/IFAS Extension Service, University of Florida, IFAS, Florida A \& M University Cooperative Extension Program, and Boards of County Commissioners Cooperating. Nick T. Place, dean for UF/IFAS Extension. 
the aquifer (i.e., ground water). FWMDs also regulate the amount of water extracted from a well by setting specific requirements according to well diameter and consumptive use permits. The consumptive use permits are described in more detail in FE604, Consumptive Use.

\section{What are water well construction requirements?}

A "well" is defined basically as any excavation to acquire, locate, or artificially recharge groundwater. Under the statutes, only licensed contractors may perform the construction, repair, or abandonment of wells. FWMDs provide testing and other licensing procedures for contractors. There are, however, some important exceptions to the requirement to hire licensed contractors. In some cases, individuals can excavate wells as long as they comply with all other local or state laws. No license is required for the following two cases (see Section 373.326(2), Florida Statutes):

- Homeowners (or renters) who construct a well two inches or less in diameter on their property for their own use (includes farming purposes). Note that the owners/renters may still be required to obtain a permit, and/ or submit a well completion report to the Water Management District. It is recommended to contact your Water Management District, local county government, or your local UF/IFAS Extension office for more information;

- In situations where the governing FWMD determines that compliance with the rules would result in unnecessary hardship for the applicant. To qualify for the undue hardship exemption, a written request must be made to the governing FWMD. Regardless of exemption qualification, FDEP must be notified of a well once it comes into existence.

Note that some Florida counties have passed local ordinances that may have stricter requirements for well construction permit applications than the state regulations. For example, Manatee County requires property owners to acquire a well construction permit for any well, including wells that are less than two inches in diameter.

Construction of a well greater than two inches in diameter (such as a three- or four-inch diameter wells that are typical for residential properties) must be performed only by licensed contractors. Homeowners constructing a well need to get a permit from both FDEP and their governing FWMD. Since permitting requirements may vary among the five FWMDs, homeowners should consult their governing FWMD for its specific permitting requirements. You can identify your governing FWMD and learn more about its permitting requirements online at the FWMD permitting portals at http://flwaterpermits.com/.

The construction, repair, or abandonment of a well will require a well permit from the appropriate FWMD. The primary exceptions to this rule include the following:

- Construction permits do not need to be obtained retroactively for wells constructed before 1972 (although permits are required to repair or abandon these wells, and if the well is determined by FDEP to be a hazard to groundwater resources)

- Construction permits do not need to be obtained when one wants to temporarily operate equipment for dewatering

- Construction permits do not need to be obtained where the district determines that requiring a permit would result in unnecessary hardship for the applicant

- Construction permits do not need to be obtained before construction, repair, or abandonment of any well exempted by Chapter 373, Florida Statutes, Sections 373.303(7) and 373.326 (such as for wells drilled for the purpose of obtaining oil, natural gas, minerals, or products of mining or quarrying, or for wells for inserting media to re-pressure oil or natural gas-bearing formations).

Remember that FWMDs also require a consumptive use permit for many withdrawals or diversions of water regardless of applicable well permitting exemptions. Also, pesticides used recklessly near wells may result in contamination of groundwater in the underlying aquifer, causing widespread pollution. Consequently, farmers should be familiar with all regulations designed to prevent water contamination before taking any action involving water wells. For more information about pesticide regulation, see FE588, FIFRA; FE589, FQPA; and FE590, FPL).

\section{Where must water well sites be placed?}

All proposed well sites must be pre-approved by the appropriate FWMD. Pre-approval protects against the possibility that a well will unknowingly be drilled in an area of existing groundwater contamination. FDEP publishes continually updated maps of contaminated sections of the aquifer to FWMDs and pertinent county health departments. This information is available on request to applicants. FWMDs and county health departments also prescribe the minimum distances from the contaminated areas at which wells may be constructed. FWMDs are also responsible for advising applicants on the minimum well placement 
distances from septic tanks, drain fields, chemical storage areas, and other potential pollution sources.

\section{What are the water well standards and specifications under state law?}

FDEP publishes basic requirements for drilling techniques and materials, grouting and sealing, identification and labeling of well heads, etc. These standards must be observed even where it is unnecessary to obtain a permit or license. Again, FWMD rules supplement FDEP requirements and should be consulted.

\section{Sources}

Chapter 373, Florida Statutes, Sections 302 to 342

Chapter 62, Florida Administrative Code, Section 531 to 532

Title 40, Florida Administrative Code

\section{Acknowledgments}

The authors are indebted to the personnel of both state and federal agencies who provided their time and advice in the preparation of this handbook. We acknowledge Carol Fountain and Susan Gildersleeve at the University of Florida for their assistance in editing this handbook. We also acknowledge funding received for updating this publication from the James S. and Dorothy F. Wershow Agricultural Law Endowment. 